\title{
Risk of Angina Pectoris, Non-Fatal Myocardial Infarction and Non-Fatal Stroke among Hypertensives: the CroHort Study
}

\author{
Ana Ivičević Uhernik, Marijan Erceg and Sandra Mihel \\ Croatian National Institute of Public Health, Zagreb, Croatia
}

\begin{abstract}
A B S T R A C T
Aim of this study was to investigate association of controlled and uncontrolled hypertension with angina pectoris, non-fatal myocardial infarction and non-fatal cerebrovascular insult on a cohort from Croatian Adult Health Cohort Study (CroHort). Odds for angina pectoris, non-fatal myocardial infarction and non-fatal cerebrovascular insult were calculated for 227 respondents with controlled hypertension and 1,287 respondents with uncontrolled hypertension compared to 1,353 normotensive respondents. The results showed that among men uncontrolled hypertension was significantly associated with risk of non-fatal stroke, while among women no significant associations were recorded. Primary and secondary prevention of hypertension should be public health priority and would contribute to reducing the risk of stroke in Croatian population.
\end{abstract}

Key words: hypertension, angina pectoris, non-fatal myocardial infarction, non-fatal stroke, CroHort study

\section{Introduction}

Cardiovascular diseases are the leading cause of mortality and one of the main causes of morbidity in Croatia with ischemic heart disease mortality of 157.75 / 100,000 and stroke mortality of 113.68 / 100,000 in 2009 (age-standardized rates) ${ }^{1}$. Worldwide, hypertension is the most important modifiable risk factor for cardiovascular diseases $^{2,3}$. In developed countries, among persons aged 35 years and more the majority have systolic and diastolic blood pressure above optimal $(120 / 80 \mathrm{mmHg}$ ), meaning that they also have increased risk of cardiovascular diseases, even if they are not hypertensive, i.e, they do not have blood pressure above the hypertension threshold of $140 / 90 \mathrm{mmHg}^{4}$. The risk for myocardial infarction and stroke increases with longer duration of hypertension ${ }^{5}$. Relative risks for cardiovascular disease associated with hypertension do not decline with advancing age $^{6}$. Data from Croatian Adult Health Survey 2003 on a nationally representative sample showed that prevalence of uncontrolled hypertension in Croatia was $40.5 \%$ for men and $34.9 \%$ for women ${ }^{7}$ and the estimation of its contribution to the burden of disease in Croatian population revealed that hypertension was situated on second place, after smoking, with $13.8 \%$ share in overall DALYs ${ }^{8}$. Hy- pertension is a known risk for occurrence of ischemic heart disease and stroke, however, incidence of hypertension and cardiovascular diseases differ among different ethnic groups depending on genetic, demographic and socioeconomic factors as well as lifestyle determinants ${ }^{9}$. Uncontrolled hypertension was found to be associated with both acute myocardial infarction and stroke ${ }^{10}$. Blood pressure level was found to be directly related to the risk of myocardial infarction and coronary heart disease in general ${ }^{11}$. Successful treatment of hypertension might reduce risk for coronary heart disease ${ }^{12}$. Achieving normotensive levels in treated hypertensive patients with uncontrolled blood pressure might prevent more than $15 \%$ of myocardial infarctions in treated hypertensive population ${ }^{13}$. Relative risk of stroke for controlled hypertensives was found to be lower than risk for uncontrolled hypertensives and did not differ significantly from that risk of normotensives in some studies ${ }^{14}$, but there were also results which revealed increased risk of cardiovascular disease among controlled hypertensives compared to normotensives ${ }^{15,16}$.

Aim of this study was to explore and compare association of controlled and uncontrolled hypertension with 
angina pectoris, non-fatal myocardial infarction and non-fatal cerebrovascular insult, for the first time on Croatian adult population cohort from Croatian Adult Health Cohort Study (CroHort).

\section{Sample and Methods}

\section{Sample}

The sample of this study consisted of 3.229 respondents (1.015 male and 2.214 female) who participated in both Croatian Adult Health Survey 2003 and the follow-up Croatian Adult Health Cohort Study (CroHort) in 2008. They were 18 years or older at the time of the first survey. Respondents who participated in 2003 , but died before 2008 survey were not included in the analysis ( 808 respondents). Further details on this sample were described elsewhere ${ }^{17}$. Respondents who reported having had myocardial infarction (135 respondents), angina pectoris (208 respondents) or cerebrovascular insult (109 respondents) in Croatian Adult Health Survey 2003 were excluded from the analysis which finally encompassed 2.867 respondents (872 male and 1.995 female).

\section{Variables}

Public health nurses measured blood pressure in respondents' homes, while diagnoses of myocardial infarction, angina pectoris and cerebrovascular insult and data on usage of medication for hypertension treatment were self-reported by respondents on both occasions and recorded on a questionnaire by public health nurses. On both occasions blood pressure was measured twice using a mercury sphygmomanometer, with respondents seated for 20 minutes between the measurements. Average systolic and diastolic blood pressures were calculated from those two measurements.

Respondents were characterized as normotensive if they had normal blood pressure (average systolic blood pressure $<140 \mathrm{mmHg}$, average diastolic blood pressure $<90 \mathrm{mmHg}$ ) and no record on usage of hypertension medications. Respondents whose average systolic and diastolic blood pressures were within normal range, but reported using hypertension medication were characterized as having controlled hypertension, while respondents whose average blood pressure was equal or higher than $140 \mathrm{mmHg}$ for systolic or equal or higher than 90 $\mathrm{mmHg}$ for diastolic blood pressure, were categorized as having uncontrolled hypertension.

Hypertension status was derived from 2003 survey data.

\section{Statistical analysis}

Numbers and percentages of respondents who stated they had myocardial infarction, angina pectoris and cerebrovascular insult in Croatian Adult Health Cohort Study (CroHort) in 2008 were calculated for normotensive respondents, respondents with controlled as well as uncontrolled hypertension, separately for men and women.

The logistic regression analysis (adjusted for age) was used to calculate OR for myocardial infarction, angina pectoris and cerebrovascular insult for respondents with controlled hypertension and for respondents with uncontrolled hypertension compared to normotensive respondents.

All confidence intervals (CI) were calculated with $95 \%$ probability levels.

Statistical analysis was performed using SPSS (version 14.01; License: Croatian National Institute of Public Health).

\section{Results}

Out of analysed 872 male respondents, 379 (43.5\%) were normotensive, $44(5.0 \%)$ had controlled hypertension and $449(51.5 \%)$ had uncontrolled hypertension,

TABLE 1

NUMBER AND PERCENTAGE OF SURVIVED RESPONDENTS WHO EXPERIENCED MI, ANGINA PECTORIS AND CVI IN THE PERIOD 2003-2008 ACCORDING TO THEIR BLOOD PRESSURE IN 2003

\begin{tabular}{|c|c|c|c|c|c|c|}
\hline & \multicolumn{3}{|c|}{ Men } & \multicolumn{3}{|c|}{ Women } \\
\hline & Number & $\%$ & $95 \% \mathrm{CI}$ & Number & $\%$ & $95 \% \mathrm{CI}$ \\
\hline \multicolumn{7}{|l|}{ Myocardial infarction } \\
\hline normotensive & 11 & 3.0 & $1.3-4.7$ & 20 & 2.2 & $1.2-3.1$ \\
\hline hypertensive - controlled & 2 & 5.0 & $0.0-11.8$ & 6 & 3.5 & $0.7-6.2$ \\
\hline hypertensive - uncontrolled & 16 & 3.7 & $1.9-5.5$ & 32 & 4.0 & $2.7-5.4$ \\
\hline \multicolumn{7}{|l|}{ Angina pectoris } \\
\hline normotensive & 11 & 3.0 & $1.3-4.7$ & 28 & 3.0 & $1.9-4.1$ \\
\hline hypertensive - controlled & 4 & 10.3 & $0.7-19.8$ & 13 & 7.6 & $3.6-11.5$ \\
\hline hypertensive - uncontrolled & 29 & 6.7 & $4.4-9.1$ & 43 & 5.4 & $3.9-7.0$ \\
\hline \multicolumn{7}{|l|}{ Cerebrovascular insult } \\
\hline normotensive & 7 & 1.9 & $0.5-3.3$ & 23 & 2.5 & $1.5-3.5$ \\
\hline hypertensive - controlled & 3 & 7.9 & $0.0-16.5$ & 10 & 5.8 & $2.3-9.3$ \\
\hline hypertensive - uncontrolled & 36 & 8.4 & $5.8-11.0$ & 37 & 4.7 & $3.2-6.1$ \\
\hline
\end{tabular}


A. Ivičević Uhernik et al.: Hypertension and Non-fatal CV Disease, Coll. Antropol. 36 (2012) Suppl. 1: 135-138

TABLE 2

ASSOCIATION OF HYPERTENSION WITH RISK OF MI, ANGINA PECTORIS AND CVI IN PERIOD 2003-2008 AMONG SURVIVED RESPONDENTS

\begin{tabular}{|c|c|c|c|c|}
\hline & \multicolumn{2}{|c|}{ Men } & \multicolumn{2}{|c|}{ Women } \\
\hline & $\mathrm{OR}^{*}$ & $95 \% \mathrm{CI}$ & $\mathrm{OR}^{*}$ & $95 \% \mathrm{CI}$ \\
\hline \multicolumn{5}{|l|}{ Myocardial infarction } \\
\hline normotensive & 1.00 & & 1.00 & \\
\hline hypertensive - controlled & 1.22 & $0.26-5.87$ & 1.04 & $0.39-2.75$ \\
\hline hypertensive - uncontrolled & 0.84 & $0.37-1.89$ & 1.18 & $0.62-2.23$ \\
\hline \multicolumn{5}{|l|}{ Angina pectoris } \\
\hline normotensive & 1.00 & & 1.00 & \\
\hline hypertensive - controlled & 2.51 & $0.73-8.61$ & 1.56 & $0.76-3.20$ \\
\hline hypertensive - uncontrolled & 1.43 & $0.68-2.98$ & 1.05 & $0.61-1.80$ \\
\hline \multicolumn{5}{|l|}{ Cerebrovascular insult } \\
\hline normotensive & 1.00 & & 1.00 & \\
\hline hypertensive - controlled & 3.51 & $0.86-14.43$ & 1.38 & $0.62-3.07$ \\
\hline hypertensive - uncontrolled & 3.47 & $1.49-8.09$ & 1.05 & $0.58-1.90$ \\
\hline
\end{tabular}

while out of 1.995 female respondents, $974(48.8 \%)$ were normotensive, $183(9.2 \%)$ had controlled hypertension and $838(42.0 \%)$ had uncontrolled hypertension in 2003.

Both among men and women, there were no significant differences recorded in percentage of respondents who experienced myocardial infarction and angina pectoris. Among men significantly higher percentage of respondents who experienced cerebrovascular insult, was recorded among those with uncontrolled hypertension compared to normotensive respondents, while among women no significant difference was recorded (Table 1).

For men, logistic regression analysis showed that having uncontrolled hypertension was associated with significant OR 3.47 for cerebrovascular insult compared to normotensive respondents, while for women that association was not found to be significant. Having uncontrolled hypertension was not associated with significantly higher OR for myocardial infarction and angina pectoris compared to normotensive respondents in both genders. Although controlled hypertension was associated with higher OR for myocardial infarction, angina pectoris and cerebrovascular insult, more intensively among men than among women, none of these associations was statistically significant (Table 2).

\section{Discussion}

Stronger association of uncontrolled hypertension with stroke than with myocardial infarction found in this research is in accordance with other studies which recorded more evident effect of increased blood pressure on risk for stroke than on risk for acute myocardial infarction $^{18}$. OR of controlled hypertensives for myocardial infarction and angina pectoris was higher compared to normotensives and OR for cerebrovascular insult was even higher than for uncontrolled hypertensives, but due to wide confidence intervals caused by small absolute number of controlled hypertensives, it did not reach statistical significance. This points out the need to explore this association on a larger number of respondents in order to ensure sufficient number of controlled hypertensives, especially in the populations like Croatian, where relatively small percentage of hypertensive respondents achieve recommended hypertension control level.

Limitations of this study included classification of respondents as normotensive, controlled or uncontrolled hypertensive according to the average from only two blood pressure measurements made in relatively short time span and on the basis of respondent's statement about usage of antihypertensive treatment which was potentially prone to response and recall bias as was the statement about having had diagnosed myocardial infarction, angina pectoris and stroke.

However, the incidence of "white coat hypertension « might have been reduced due to the fact that blood pressure measurements were made during public health nurse's visit to respondent's home. Blood pressure values measured at respondent's home were found to be more intensively related to the risk of stroke than blood pressure values measured in doctor's office ${ }^{19}$, which might have contributed to recorded association of uncontrolled hypertension with stroke in this study.

This research confirmed the importance of hypertension as major unsolved mass public health problem. The association of uncontrolled hypertension with non-fatal stroke recorded among male population emphasizes significant potential for improvement of health and longevity in Croatian population through effort on prevention of hypertension. Its realization would require population wide primary prevention aimed to prevent increase in blood pressure with age as well as high risk approach through secondary prevention encompassing improvement of early detection, treatment and control of hypertension $^{20}$ 


\section{Acknowledgements}

This article was prepared as a part of scientific project »Regionalism of cardiovascular behavioural risk factors - model of intervention « (108-1080135-0264) supported by Ministry of Science, Education and Sport of the Republic of Croatia.

\section{R E F E R E N C E S}

1. European health for all database, accessed on 24th May 2011. Available from: URL: http://data.euro.who.int/hfadb/. - 2. KEARNEY P, WHELTON M, REYNOLDS K, MUNTNER P, HE J, Lancet, 365 (2005) 217. - 3. LOPEZ A, MATHERS C, EZZATI M, JAMISON D, MURRAY C. Lancet 367 (2003) 1747. - 4. STAMLER J, STAMLER R, NEATON JD Arch Intern Med 153 (1993) 598. - 5. GUO XH, ZHANG PH, ZENG ZC WANG W, LI C, SHI Y, LIU ZJ. Clin Exp Hypertens, 31 (2009) 142. — 6 LLOYD-JONES DM, EVANS JC, LEVY D. JAMA, 294 (2005) 466. - 7. ERCEG M, KERN J, BABIĆ-ERCEG A, IVIČEVIĆ UHERNIK A, VULETIĆ S. Coll Antropol, 33 (Suppl 1) (2009) 19. - 8. WHO, The European health report 2005: Public health action for healthier children and populations (WHO, Geneva, 2005). - 9. WOLF-MAIER K, COOPER RS, BANEGAS JR, GIAMPAOLI S, HENSE HW, JOFFRES M, KASTARINEN M, POULTER N, PRIMATESTA P, RODRIGUEZ-ARTALEJO F, STEGMAYR B, THAMM M, TUOMILEHTO J, VANUZZO D, VESCIO F, JAMA, 289 (2003) 2363. - 10. AL-ROOMI KA, HELLER RF, WLODAR CZYK J, Med J Aust, 153 (1990) 595, 602. — 11. BAKX JC, VELDSTRA MI, VAN DEN HOOGEN HM, ZIELHUIS GA, THIEN T, VAN WEEL C,
VAN DEN BOSCH WM, Prev Med, 32 (2001) 142. - 12. WILSON PW, ANDERSON KM, CASTELLI WP, Am J Med, 90 (1991) 11. - 13. KAPLAN RC, PSATY BM, HECKBERT SR, SMITH NL, LEMAITRE RN, Am J Public Health, 89 (1999) 1414. - 14. FANG XH, ZHANG XH, YANG QD, DAI XY, SU FZ, RAO ML, WU SP, DU XL, WANG WZ, LI SC, Stroke 37 (2006) 38. - 15. KELLY TN, GU D, CHEN J, HUANG JF, CHEN JC, DUAN X, WU X, YAU CL, WHELTON PK, HE J, Circulation, 118 (2008) 1558. - 16. ALMGREN T, PERSSON B, WILHELMSEN L, ROSENGREN A, ANDERSSON OK, Intern Med, 257 (2005) 496. — 17. IVIČEVIĆ-UHERNIK A, VULETIĆ S, KERN J, DEČKOVIĆ-VUKRES V, MIHEL S, ERCEG M, PRISTAŠ I, Coll Antropol 36 (Suppl 1) (2012) 3. 18. ISEKI K, KIMURA Y, WAKUGAMI K, OKUMURA K, MURATANI H, IKEMIYA Y, FUKIYAMA K, Hypertens Res, 23 (2000) 143. - 19. OHKUBO T, ASAYAMA K, KIKUYA M, METOKI H, OBARA T, SAITO S, HOSHI H, HASHIMOTO J, TOTSUNE K, SATOH H, IMAI Y, Blood Press Monit, 9 (2004) 315. - 20. STAMLER J, STAMLER R, NEATON JD, Arch Intern Med, 153 (1993) 598.

\section{A. Ivičević Uhernik}

Croatian National Institute of Public Health, Rockefellerova 7, 10000 Zagreb, Croatia

e-mail: ana.ivicevic@hzjz.hr

\section{RIZIK OD POJAVE ANGINE PECTORIS, NEFATALNOG INFARKTA MIOKARDA I NEFATALNOG MOŽDANOG UDARA KOD HIPERTONIČARA: CroHort STUDIJA}

\section{S A Ž E T A K}

Cilj ovog rada bio je istražiti povezanost kontrolirane i nekontrolirane hipertenzije s anginom pektoris, nefatalnim infarktom miokarda i nefatalnim moždanim udarom na kohorti iz Hrvatske kohortne studije kardiovaskularnog zdravlja. Rizici od pojave angine pektoris, nefatalnog infarkta miokarda i nefatalnog moždanog udara izračunati su za 227 ispitanika s kontroliranom hipertenzijom i 1,287 ispitanika s nekontroliranom hipertenzijom u usporedbi s 1,353 ispitanika s normalnim tlakom. Rezultati su pokazali da je kod muškaraca nekontrolirana hipertenzija bila značajno povezana s rizikom za nefatalni moždani udar, dok kod žena nisu zabilježene značajne povezanosti. Primarna i sekundarna prevencija hipertenzije trebale bi biti javnozdravstveni prioriteti čime bi se pridonijelo smanjenju rizika od pojave moždanog udara u hrvatskoj populaciji. 